\title{
Evaluasi Kapasitas Kepala Jembatan Akibat Perubahan Beban Gempa Rencana Sesuai SNI 2833:2016
}

\author{
Fachri Pangestu $^{1)}$, Andi Indianto ${ }^{2)}$ \\ 1),2) Jurusan Teknik Sipil, Politeknik Negeri Jakarta, Jl. Prof. DR. G.A. Siwabessy, Kampus Baru \\ UI, Kukusan, Kecamatan Beji, Kota Depok, Jawa Barat, 16424. \\ Email : fachri.pangestu.ts17@mhsw.pnj.ac.id ${ }^{1}$, andipoltek@gmail.com²
}

\begin{abstract}
Abstrak
Pelaksanaan kepala jembatan X dilakukan di tahun 2015 yang direcanakan pada tahun 2013 masih menggunakan peraturan yang terdahulu yaitu SNI 2833:2008. Sehubungan dengan dikeluarkanya peraturan baru yaitu SNI 2833:2016 maka terdapat perubahan beban gempa rencana dari peraturan lama ke baru sehingga perlu dilakukan evaluasi terhadap kapasitas kepala jembatan terhadap beban gempa rencana sesuai SNI 2833:2016 dan dilakukan justifikasi perkuatan apabila kepala jembatan tidak layan menerima beban yang bekerja . Evaluasi kapasitas kepala jembatan dilakukan dengan cara melakukan pengecekan terhadap kapasitas dimensi, kapasitas tulangan, kapasitas daya dukung pada pondasi dan lendutan menggunakan software SAP2000 untuk menganalisisnya. Hasil penelitian menunjukan bahwa kapasitas pada dimensi kebutuhan tulangan didalam dimensi kepala jembatan masih memadai di semua bagian, kapasitas tulangan yang terpasang disetiap bagian kepala jembatan lebih besar dari hasil analisis sehingga masih kuat menahan beban yang bekerja, kapasitas daya dukung pondasi yang lebih kecil dibandingkan dengan daya dukung izin dan lendutan yang terjadi dibawah yang diizinkan, maka kepala jembatan masih kuat menerima beban yang bekerja sehingga tidak dilakukan justifikasi perkuatan.
\end{abstract}

Kata kunci : Beban Gempa Rencana, Evaluasi, Kepala Jembatan, Perkuatan.

\begin{abstract}
The implementation of the X abutment was carried out in 2015 which was planned in 2013 still using the previous regulation, namely SNI 2833:2008. In connection with the issuance of a new regulation, namely SNI 2833:2016, there is a change in the design earthquake load from the old regulation to the new so that it is necessary to evaluate the capacity of the abutment against the design earthquake load according to SNI 2833:2016 and justify the reinforcement if the abutment is not serviced to receive a heavy load. work. The evaluation of the abutment capacity is carried out by checking the dimensional capacity, reinforcement capacity, bearing capacity of the foundation and deflection using SAP2000 software to analyze it. The results showed that the capacity in the dimensions of the reinforcement requirements in the dimensions of the abutment was still adequate in all parts, the capacity of the reinforcement installed in each part of the abutment was greater than the results of the analysis so that it was still strong enough to withstand the working load, the bearing capacity of the foundation was smaller than the capacity of the foundation. permit support and deflection that occurs below the permitted, then the bridge head is still strong enough to accept the working load so that reinforcement is not justified.
\end{abstract}

Keywords : Abutment, Design earthquake load, Evaluation, Reinforcement.

Copyright $(2021$ The Author(s)

This is an open access article under the $\mathrm{CC}$-NC-SA license. 


\section{PENDAHULUAN}

Perencanaan kepala jembatan proyek X dilakukan di tahun 2013 dan kemudian dibangun pada tahun 2015 masih menggunakan peraturan yang terdahulu yaitu SNI 2833:2008 dengan umur rencana 50 tahun dan saat ini umur jembatan telah mencapai 6 tahun, sehingga Berdasarkan NSPM (Norma, Standar, Pedoman dan Manual) Pemeriksaan, setiap 5 tahun sekali harus dilakukan pemeriksaan detail salah satunya berupa evaluasi kelayanan dan kekuatan pada jembatan. Evaluasi dilakukan terhadap kapasitas kepala jembatan sesuai dengan SNI (Standar Nasional Indonesia) 2833:2016. Justifikasi perkuatan dilakukan dengan memilih tipe perkuatan yang tepat apabila kapasitas kepala jembatan tidak kuat dan layan menerima beban yang bekerja sesuai SNI 2833:2016.

Kondisi Indonesia saat ini merupakan negara khatulistiwa yang didalamnya terdapat cincin api Pasifik (Pasific ring of fire). Di dalam cincin api ini terdapat barisan gunung berapi aktif dan plat tektonik atau lempeng bumi yang terdiri dari lempeng Eurasia, lempeng Pasifik dan lempeng Indo-Australia yang bergerak dan bertumbukan satu sama lain yang menyebabkan pergerakan tanah atau terjadinya gempa, sehingga Indonesia merupakan salah satu negara yang rawan terjadinya gempa (Kastama et al., 2016).

Gempa bumi menjadi bencana alam dengan frekuensi kejadian terbesar kelima di Indonesia setelah banjir, tanah longsor, puting beliung dan kekeringan. Terjadinya gempa menghasilkan energi yang kuat yang menjalar di permukaan bumi dengan gelombang vertikal dan horizontal (Wulandari S, 2013).

Diperlukan penggunan standar baru dalam perencanaan jembatan terhadap beban gempa rencana dikarenakan kondisi kegempaan dan state of the art seismic hazard analysis dan reliability analysis yang terus berkembang dibandingkan kondisi sebelumnya. Standar perencanaan jembatan terhadap beban gempa yang terkini tertuang dalam SNI (Standar Nasional Indonesia) 2833:2016, peraturan terbaru ini memiliki nilai yang jauh lebih besar dari pada peraturan sebelumnya yaitu, SNI (Standar Nasional Indonesia) 2833:2008. Oleh karena itu Jembatan existing perlu dievaluasi menggunakan standar terbaru.

Dalam Penelitian Nindi Rizki Apriliani (Apriliani et al., 2020) yang berjudul Tinjauan Kapasitas abutment Jembatan Sengkaling Malang Dengan Beban Gempa, dilakukan analisis kombinasi dari beban beban kerja pada abutment terhadap daya layan dan ekstrim menggunakan peraturan pembebanan pada jembatan yaitu, SNI (Standar Nasional Indonesia) 1725:2016 dan peraturan perencanaan jembatan terhadap beban gempa yaitu, SNI (Standar Nasional Indonesia) 2833:2016. Hasil dari analisis tersebut menunjukan bahwa kapasitas abutment pada jembatan tersebut jika terjadi gempa yang menggunakan SNI 2833:2016 akan mengalami guling karena stabilitas geser dan guling arah $\mathrm{X}$ abutment tidak layan dalam menerima beban dan ketinggian abutment kurang memadai sehingga tidak dapat menopang beban jika terjadi gempa.

Jembatan adalah prasarana lalu-lintas yang memiliki fungsi untuk menghubungkan jalan yang terputus oleh sungai, lembah, laut, danau ataupun bangunan lain dibawahnya (Andi Indianto, 2020). Suatu jembatan berfungsi untuk melayani arus lalu lintas dengan baik, dalam perencanaan dan perancangan jembatan sebaiknya mempertimbangkan fungsi kebutuhan transportasi, persyaratan teknis dan estetikaarsitektural yang meliputi Aspek lalu lintas, Aspek teknis, Aspek estetika(Supriyadi, 2007).

Kepala Jembatan adalah bangunan bawah jembatan yang terletak pada kedua ujung pilar-pilar jembatan, berfungsi sebagai pemikul seluruh beban hidup (kendaraan, angin, air, dan lain-lain) dan beban mati (beban gelagar dan lain-lainnya) pada jembatan. Beban hidup, beban mati dari jembatan dan beban dari abutmen akan 
diterima oleh pondasi tiang bor yang akan diteruskan pada tanah (Chen , 2000).

Pondasi tiang bor (bored pile) adalah pondasi tiang yang pemasangannya dilakukan dengan mengebor tanah pada awal pengerjaannya. Bored pile dipasang ke dalam tanah dengan cara mengebor tanah terlebih dahulu, baru kemudian diisi tulangan dan dicor beton (Wilis, 2019).

Daya dukung aksial pondasi bored pile terdiri dari gabungan daya dukung ujung dan daya dukung akibat gesekan tiang dengan tanah sekelilingnya. Kapasitas daya dukung pondasi bored pile dipengaruhi oleh jarak antar tiang bor, bila saling berdekatan daya dukung antar tiang saling mempengaruhi, maka harus dibangun dengan jarak minimum dua kali diameter tiang (Suhairiani dkk, 2017).Kapasitas daya dukung lateral pondasi boredpile bekerja pada ujung atas (kepala tiang) dengan menahan beban lateral akibat beban gempa dan beban lainnya. Pada kondisi tersebut akan timbul gaya geser tiang dan momen lentur sebagai akibat terdeformasinya kepala tiang ke arah lateral (Darmawan et al., 2017).

Sisa Kapasitas Jembatan, faktor penyebab perlu adanya penentuan nilai kapasitas jembatan Berdasarkan (Direktorat Jenderal Bina Marga, 2011). tentang Penentuan Nilai yaitu berlaku nya standar baru.

Tahapan dalam melakukan evaluasi kapasitas struktur dapat dilakukan secara analisis mulai dari perhitunganpembebanan, analisis struktur, cek kapasitas penampang dan tulangan, serta cek kapasitas pondasi (Direktorat Jenderal Bina Marga,2020).

Pembebanan pada Kepala Jembatan Pada perencanaan struktur kepala jembatan standar peraturan yang digunakan untuk menganalisa pembebanan yang akan di pikul ialah standar peraturan SNI 1725:2016 (Badan Standarisasi Nasional Indonesia, 2016) tentang pembebanan untuk jembatan dan SNI 2833:2016 (Badan Standardisasi Nasional Indonesia, 2016) tentang perencanaan jembatan terhadap beban gempa. Pembebanan meliputi beban mati, beban mati tambahan, beban gempa.

\section{METODE PENELITIAN}

Tahapan Penelitian dilaksanakan sebagai berikut.

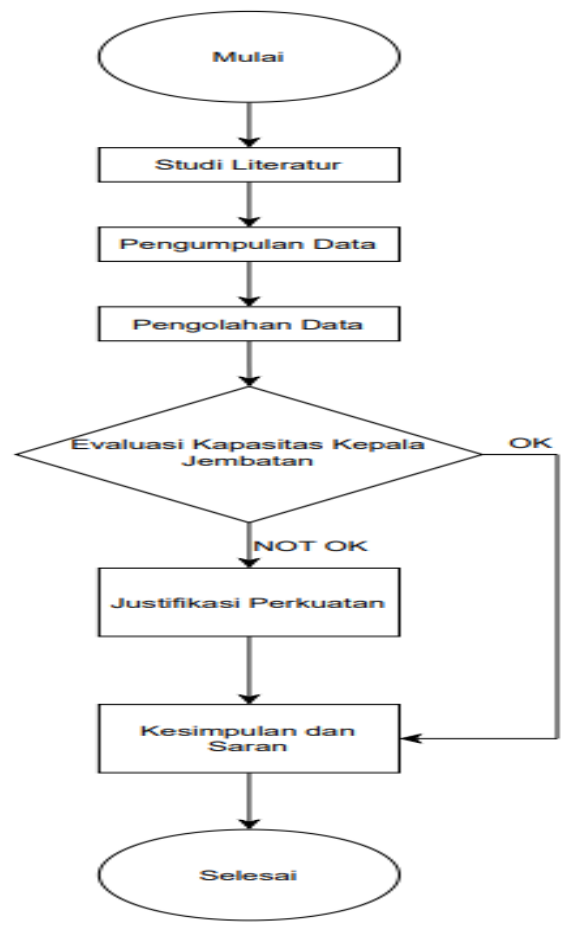

Gambar 1. Diagram Alir Penelitian

Tahapan penelitian dimulai dari mencari studi literatur yang didapatkan dari buku, jurnal, SNI, kemudian dilakukan pengumpulan data sekunder berupa data Gambar rencana atau DED (Detail Engineering Design) dan data tanah dari pihak terkait. Dari data yang telah didapatkan kemudian diolah untuk dihitung pembebanan, terutama beban gempa rencana sesuai SNI 2833:2016 pada kepala jembatan. Setelah dilakukan perhitungan pembebanan maka dianalisis menggunakan software SAP2000. Hasil analisis tersebut digunakan untuk mengevaluasi kapasitas kepala jembatan, seperti kapasitas dimensi, kapasitas tulangan dan kapasitas daya dukung pondasi. Jika kapasitas kepala jembatan masih layan dan kuat menerima beban gempa rencana sesuai SNI 2833:2016 maka dilanjutkan menuju kesimpulan, namun jika kepala jembatan tidak kuat dan 
layan menerima beban yang bekerja maka dilakukan justifikasi perkuatan yang sesuai.

\section{HASIL DAN PEMBAHASAN}

Penggunaan SNI 2833:2008 terkait beban gempa rencana berubah menjadi SNI 2833:2016 dikarenakan ada peraturan terbaru. Perubahan Beban Gempa rencana tersebut akan mempengaruhi kapasitas kepala jembatan. Berikut Analisa perhitungan perubahan beban gempa rencana dari SNI 2833:2008 ke SNI 2833:2016.

Beban gempa rencana menurut SNI 2833:2008 sebagi berikut.

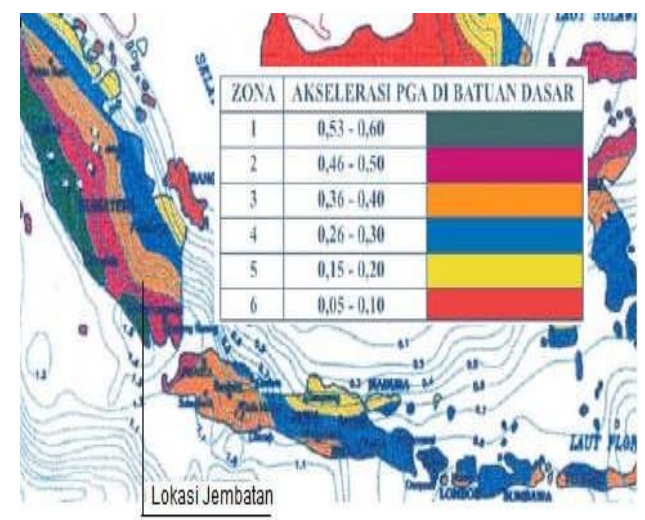

Gambar 2. Peta PGA Gempa SNI 2833:2008

Berdasarkan Gambar 2 tersebut, peta PGA Gempa pada SNI 2833:2008 Standar pembebanan gempa untuk Jembatan, lokasi jembatan diatas masuk wilayah 3 dengan periode ulang gempa 500 tahun, didapatkan dengan nilai 0,4 .

Didapatkan prosedur analisis menggunakan cara analisis 1, yaitu Menggunakan cara analisis statis beban seragam atau koefisien gempa.

Dengan didapatkan nilai PGA sebesar 0,4 maka Kinerja Seismik yaitu D dengan klasifikasi jembatan utama.

Cara Statis dengan Koefisien gempa, dengan beban gempa seragam jembatan Jalan Nasional I sebesar 1,2 dengan kategori Jembatan Utama.

Untuk kepala Jembatan didapatkan nilai $\mathrm{R}$ sebesar 0,8 .Jenis tanahnya adalah jenis tanah sedang ( Hard soil pada kedalaman 11 $\mathrm{m}$ dari permukaan tanah) didapatkan nilai $\mathrm{S}$ sebesar 1,2.

Waktu getar gempa arah memanjang jembatan (T) Hasil SAP $=0,19$ detik. Dengan waktu getar $=0,19 \mathrm{dt}$, dan jenis kepala jembatan berupa kolom tunggal, maka nilai z sebesar 6 .

$$
\begin{aligned}
& \text { Cplastis }=\frac{A \times R \times S}{Z} \\
& \text { Cplastis }=\frac{0,4 \times 0,8 \times 1,2}{6} \\
& \text { Cplastis }=0,064 \\
& E Q=C \times F S \times I \times W t \\
& E Q=0,064 \times 1,625 \times 1,2 \times W t \\
& E Q=0,125 \mathrm{Wt}
\end{aligned}
$$

Beban gempa rencana menurut SNI 2833:2016 sebagai berikut.

Berdasarkan Persyaratan analisis minimum untuk pengaruh gempa, bahwa jembatan dengan bentang tunggal disemua zona gempa dari $1-4$ hanya menggunakan beban gempa statik dan tidak menggunakan beban gempa dinamis.

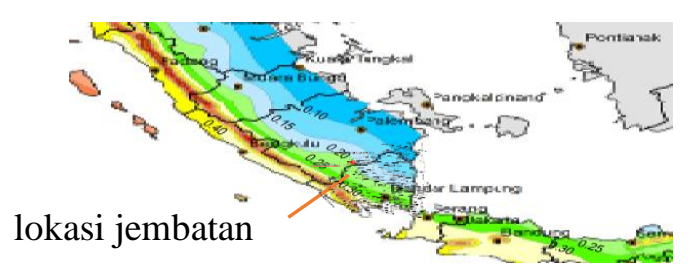

Gambar 3. Peta PGA SNI 2833:2016

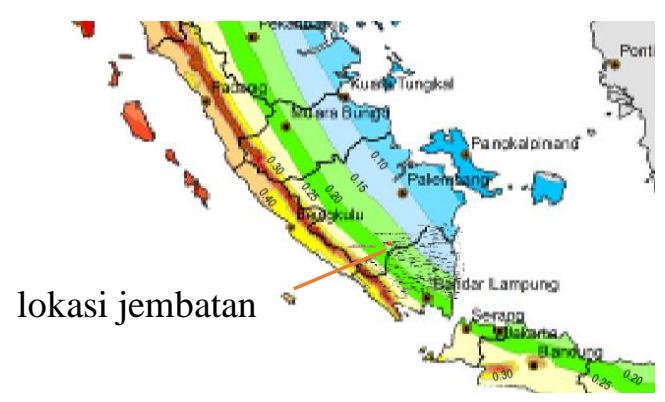

Gambar 4. Peta SS SNI 2833:2016 


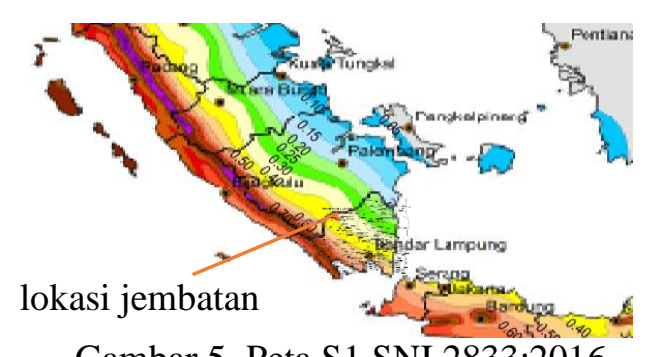

Gambar 5. Peta S1 SNI 2833:2016

Berdasarkan Gambar 3, Gambar 4, Gambar 5 tersebut didapatkan dari Peta PGA, Ss, S1 pada SNI 2833:2016, maka diperoleh nilai sebagai berikut.

$$
\begin{array}{ll}
\text { PGA } & =0,24 \\
\text { Ss } & =0,43 \\
\mathrm{~S}_{1} & =0,21
\end{array}
$$

Faktor amplikasi didapatkan dari kelas situs, untuk mencari kelas situs didapatkan dari Kondisi tanah berdasarkan data Sondir.

Dari penentuan kelas situs, maka diperoleh faktor amplikasi sebagai berikut.

$$
\begin{array}{ll}
\mathrm{F}_{\mathrm{PGA}} & =1,32 \\
\mathrm{Fa} & =1,46 \\
\mathrm{Fv} & =1,98
\end{array}
$$

Maka diperoleh :

$$
\begin{array}{rl}
\mathrm{As} & =\mathrm{PGA} x \mathrm{~F}_{\mathrm{PGA}} \\
& =0,24 x 1,32 \\
& =0,317 \\
\mathrm{~S}_{\mathrm{DS}} & =\mathrm{S}_{\mathrm{S}} x \mathrm{Fa} \\
& =0,43 \times 1,46 \\
& =0,626 \\
& =\mathrm{Fv} x \mathrm{~S}_{1} \\
\mathrm{~S}_{\mathrm{D} 1} & =1,98 x 0,21 \\
& =0,416 \\
& =\mathrm{S}_{\mathrm{D} 1} / \mathrm{S}_{\mathrm{DS}} \\
\mathrm{T}_{\mathrm{S}} & 0,416 / 0,626 \\
& =0,664
\end{array}
$$


jembatan, lantai kerja jembatan, trotoar, parapet, kepala jembatan, pile cap dan pondasi.

Beban mati tambahan meliputi berat aspal. Aspal dibuat dengan ketebalan $5 \mathrm{~cm}$. Berat aspal tersebut dihitung dengan persamaan berikut.

Beban aspal $\quad=0,05 \mathrm{~m} \times 2,2 \mathrm{t} / \mathrm{m}^{3}$

$$
=0,11 \mathrm{t} / \mathrm{m}^{2}
$$

Beban hidup bekerja pada struktur atas, beban hidup tersebut terdiri dari beban garis terpusat (BGT), beban terbagi rata (BTR), dan gaya rem kendaraan.

Besarnya nilai Beban Garis Terpusat (BGT) sesuai dengan ketentuan SNI 1725:2016 adalah $49 \mathrm{kN} / \mathrm{m}$ dikali dengan faktor beban dinamis. Didapatkan nilai FBD sebesar 38\%.

Beban garis terpusat diasumsikan bekerja pada tumpuan jembatan sebagai beban titik (P) yang bekerja pada as girder dengan lebar tinjauan 1,4 m. Maka beban P dapat dihitung sebagai berikut.

$$
\begin{aligned}
\mathrm{P} & =(49 \mathrm{kN} / \mathrm{m} x(1+0,38)) \times 1,4 \mathrm{~m} \\
& =94,69 \mathrm{kN} \\
& =9,469 \mathrm{ton}
\end{aligned}
$$

Beban terbagi rata untuk jembatan dengan bentang lebih dari $30 \mathrm{~m}$ dapat dihitung dengan persamaan berikut.

$$
\begin{aligned}
\mathrm{q}(\mathrm{L}>30 \mathrm{~m}) & =9 x\left(0,5+\frac{15}{50,8}\right) \\
& =0,72 \mathrm{t} / \mathrm{m}^{2}
\end{aligned}
$$

Beban pejalan kaki bekerja pada trotoar sebagai beban merata, jika lebar trotoar lebih besar dari $600 \mathrm{~mm}$, maka digunakan beban pejalan kaki sebesar $5 \mathrm{kPa}$ atau $0,5 \mathrm{t} / \mathrm{m}^{2}$

Beban yang dihasilkan akibat adanya gaya rem pada kendaraan bekerja secara horizontal serah dengan datangnya kendaraan. Beban akibat gaya rem dihitung menggunakan persamaan berikut dengan berat gandar truk sebesar $225 \mathrm{kN}$ dan berat truk sebesar $500 \mathrm{kN}$.
$\mathrm{TB} \quad=25 \% \times$ Berat gandar truk (14)

$$
\begin{aligned}
& =25 \% \times(500 \times 2) \mathrm{kN} \\
& =250 \mathrm{kN} / \text { lajur lalu lintas }
\end{aligned}
$$

Dari hasil perhitungan diatas, maka beban yang dihasilkan akibat pengereman digunakan sebesar $250 \mathrm{kN}$ bekerja pada setiap lajur lalu lintas. Terdapat 2 lajur dengan jumlah girder sebanyak 6 buah. Maka beban akibat gaya rem kendaraan yang bekerja pada girder sebagai berikut.

\section{Beban Pengereman}

$=$ TB $x$ (Jumlah lajur $/$ jumlah girder)

$=56,25 \mathrm{kN} x(2 / 6) / 50 \mathrm{~m}$

$=83,3 \mathrm{kN} /$ girder

$=0,16 \mathrm{t} /$ girder

Beban gempa rencana struktur atas yang bekerja arah memanjang jembatan diasumsikan pada tengah bentang. Jumlah girder sebanyak 6 pada. Maka beban gempa rencana yang bekerja pada girder sebesar :

$$
\begin{aligned}
& \text { EQ } \quad=0,417 x \mathrm{Wt} \\
& \text { EQ } \quad=0,417 \times 597,4 \text { ton } \\
& \text { EQ } \quad=323,2 \text { ton } \\
& \mathrm{EQ} / \text { girder } \quad=\mathrm{EQ} / \text { jumlah girder } \\
& =323,2 \text { ton } / 6 \\
& =53,8 \text { ton }
\end{aligned}
$$

Beban gempa tersebut bekerja pada pusat massa jembatan dengan dua kombinasi.

Gempa sebesar 53,8 ton arah $\mathrm{x}$

Kondisi tanah pada sekeliling pondasi bored pile yang terbenam di dalam tanah dibuat model dengan konstanta pegas tanah atau spring dengan besaran sesuai dengan nilai $\mathrm{N}$-spt pada setiap kedalaman tanah.

Pemodelan Kepala Jembatan dalam bentuk 3D pada software SAP2000 pada Gambar 6 terdiri dari pondasi bored pile, pile cap, kepala jembatan, dan struktur atas. 


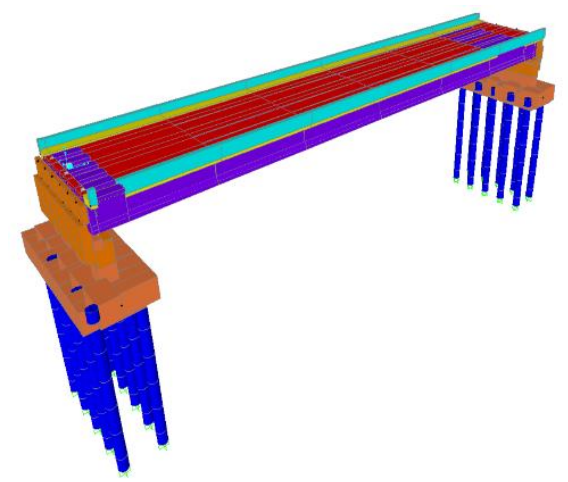

Gambar 6. Pemodelan Struktur

Setelah dilakukan pemodelan pada struktur dan memasukkan data material, pembebanan, maka dilakukan analisis struktur. Hasil analisis yang dilakukan menggunakan software SAP2000, menunjukan bahwa kondisi tegangan beton disetiap elemen kepala jembatan tidak mengalami overstress. Kemudian dilakukan pengecekan terhadap kapasitas tulangan.Pengecekan terhadap kapasitas tulangan dilakukan dengan cara mencari jumlah tulangan dari As perlu yang diperoleh dari hasil analisis di SAP2000, dan dibandingkan dengan jumlah tulangan yang telah terpasang.

Tabel 1.Tulangan Longitudinal

\begin{tabular}{ccc}
\hline \multirow{2}{*}{ Elemen } & \multicolumn{2}{c}{ Tulangan Longitudinal } \\
\cline { 2 - 2 } $\begin{array}{c}\text { Aktual } \\
\text { Back wall }\end{array}$ & $\begin{array}{c}\text { D19- } \\
\text { depan dan } \\
\text { belakang }\end{array}$ & D19-150 \\
\hline $\begin{array}{c}\text { Wall depan } \\
\text { dan belakang }\end{array}$ & D19-75 & D19-80 \\
\hline $\begin{array}{c}\text { Pondasi } \\
\text { Bore Pile A }\end{array}$ & D19-89 & D19-93 \\
\hline $\begin{array}{c}\text { Pondasi } \\
\text { Bore Pile B }\end{array}$ & D19-114 & D19-140 \\
\hline
\end{tabular}

Tabel 2. Tulangan Pengekang

\begin{tabular}{ccc}
\hline Elemen & \multicolumn{2}{c}{ Tulangan Pengekang } \\
& Aktual & Kebutuhan \\
\hline $\begin{array}{c}\text { Back Wall } \\
\text { depan dan } \\
\text { belakang }\end{array}$ & D13-300 & D13-500 \\
\hline $\begin{array}{c}\text { Wall depan dan } \\
\text { belakang }\end{array}$ & D13-400 & D13-1100 \\
\hline $\begin{array}{c}\text { Pondasi Bore } \\
\text { Pile A }\end{array}$ & $\varnothing 10-50$ & $\emptyset 10-135$ \\
\hline $\begin{array}{c}\text { Pondasi Bore } \\
\text { Pile B }\end{array}$ & $\varnothing 8-90$ & $\varnothing 8-105$ \\
\hline
\end{tabular}

Tabel 3. Tulangan longitudinal pile cap

\begin{tabular}{lrrrrr}
\hline \multirow{3}{*}{ Elemen } & \multicolumn{3}{c}{ Tulangan Longitudinal } \\
\cline { 2 - 3 } & \multicolumn{2}{c}{ Aktual } & & \multicolumn{1}{c}{ Kebutuhan } \\
\cline { 2 - 3 } Pilecap & Top & Bottom & & Top & Bottom \\
melintang & D19- & D19- & & D19- & D19- \\
\hline Pilecap & 150 & 75 & & 250 & 100 \\
memanjang & D16- & D16- & D16- & D16- \\
\hline
\end{tabular}

Tabel 4. Tulangan Pengekang pile cap

\begin{tabular}{ccc}
\hline Elemen & \multicolumn{2}{c}{ Tulangan Pengekang } \\
\hline $\begin{array}{c}\text { Pilecap } \\
\text { melintang }\end{array}$ & Dktual & Kebutuhan \\
\hline $\begin{array}{c}\text { Pilecap } \\
\text { memanjang }\end{array}$ & D16-150 & D16-225 \\
\hline
\end{tabular}

Berdasarkan tabel 1, tabel 2, tabel 3, tabel 4 tersebut, didapatkan jarak antar tulangan longitudinal dan pengekang dari hasil analisa lebih besar dibandingkan dengan yang terpasang sehingga kepala jembatan masih layan menerima beban yang bekerja.

\section{Kapasitas daya dukung pondasi}

Qu ijin didapatkan sebesar 211,3 ton

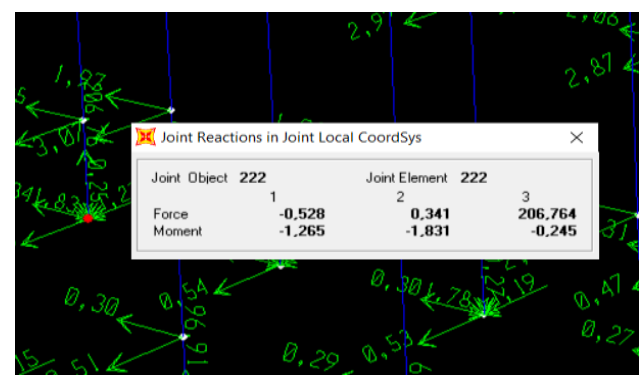

Gambar 7. Daya dukung pondasi

P maks pada pondasi bore pile diperoleh dari software SAP2000 sebesar 206,7 ton berdasarkan Gambar 7, karena P maks lebih kecil dari Qu izin, maka kapasitas daya dukung pondasi kuat menahan beban yang bekerja.

Nilai Lendutan yang didapatkan harus lebih kecil dari lendutan izin L/800 yaitu 63,5 mm. Didapatkan lendutan yang terjadi pada girder sebesar 2,86 mm, maka lendutan tersebut berdasarkan Gambar 8 dibawah lendutan yang diizinkan. Dengan hasil 
tersebut, dapat dikatakan bahwa girder pada jembatan kuat menahan beban yang bekerja.

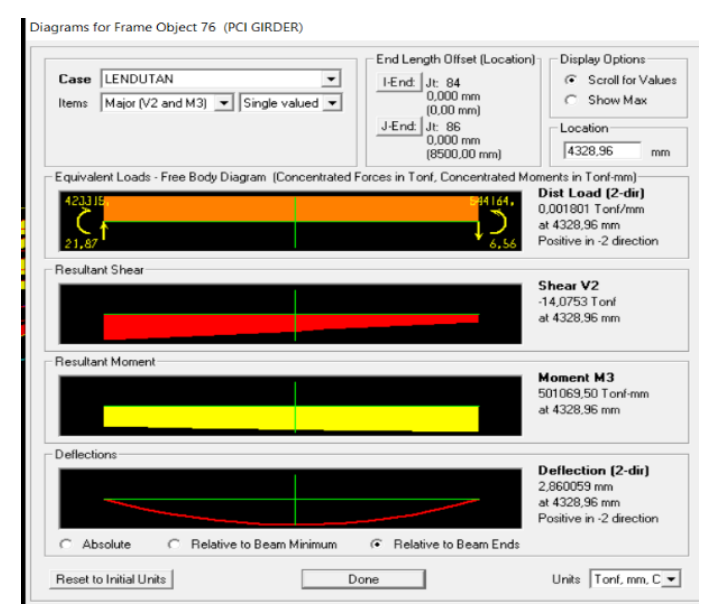

Gambar 8. Lendutan pada girder

Berdasarkan hasil Analisa didapatkan kapasitas dimensi tidak mengalami overstress yaitu kondisi tulangan memadai didalam dimensi, kapasitas tulangan memadai disetiap bagian kepala jembatan karena jarak antar tulangan analisa lebih besar dibandingkan jarak tulangan yang terpasang sehingga dalam jumlah tulangan yang terpasang lebih besar dari jumlah tulangan hasil analisa sehingga kuat menahan beban yang bekerja, kapasitas daya dukung pondasi memadai karena Pmaks lebih kecil dari Qu yang diizinkan dan cek lendutan pada girder memadai karena lendutan yang terjadi analisa lebih kecil dibandingkan lendutan izin, maka kapasitas jembatan secara keseluruhan memadai dan kuat menahan beban yang bekerja akibat beban gempa rencana sesuai SNI 2833:2016.

\section{KESIMPULAN}

Berdasarkan hasil evaluasi dengan beban gempa rencana mengacu pada SNI 2833:2016, kapasitas kepala jembatan Way Tahmi masih memenuhi kelayanan.

Berdasarkan hasil Analisa kepala jembatan dalam kondisi layan, maka tidak diperlukan justifikasi perkuatan.

\section{DAFTAR PUSTAKA}

Kastama, Y. F., Sudika, I. G. M., \& Astarian, N. K. (2016). Perbandingan Perilaku Struktur Beton Bertulang Terhadap Beban Gempa Berdasarkan SNI 03-1726-2002 dan 031726-2012.

Wulandari S. 2013. Analisis Dan Evaluasi Struktur Atas Tower C Grand Center Point Apartment Terhadap Beban Gempa Berdasarkan Peta Gempa Indonesia 2010 .Skripsi. Bogor (ID): Institut Pertanian Bogor.

Rizki, Nindi (2020). Tinjauan Kapasitas Abutment Jembatan Sengkaling Malang Dengan Beban Gempa. Jember: Universitas Muhammadiyah Jember.

Indianto. A. (2020). Modul Kuliah Konstruksi Jembatan 1. Jakarta : Politeknik Negeri Jakarta.

Supriyadi (2007). Modul Kuliah Jembatan . Manado : Universitas Katholik Della Salle.

Chen, Wai Fah, Duan, Lian. (2000). Bridge Engineering 1 Handbook. London.

Wilis, Widya Lely (2019) Studi Alternatif Perencanaan Abutment Dan Pondasi Bored Pile Pada Jembatan Sambirejo STA 163+144 Tol Solo - Kertosono Fase 1. Skripsi thesis, ITN Malang.

Suhairiani, Roesyanto, Iskandar, R. (2017). "Analisis Perbandingan Daya Dukung Hasil Loading Test Pada Bore Pile Diameter Satu Meter Tunggal Dengan Metode Elemen Hingga Memakai Model Tanah Mohr Coulomb Pada Proyek Crystal Square Medan". Jurnal Education Building. ISSN: 2477-4898. Volume 3, Nomor1.

Siregar, Muhammad Fahmi. (2018). Analisis Daya Dukung Dan Penurunan Elastik Pondasi Tiang Bor (Bored Pile) Dengan Menggunakan Metode Analitis Dan Software Plaxis V.8.6 (Studi Kasus Proyek Jalan Layang Kereta Api Medan Bandar Khalipah KM 0+600). Medan: Universitas Sumatera Utara.

Direktorat Jenderal Bina Marga. (2011). Pedoman Konstruksi dan Bangunan no. 024/BM/2011 :Penentuan Nilai Kapasitas Jembatan.

Direktorat Jenderal Bina Marga. (2020). Surat Edaran Nomor : 04/SE/Db/2020 tentang Panduan Teknis Evaluasi Struktur Jembatan Untuk Dispensasi Penggunaan Jalan Yang Memerlukan PerlakuanKhusus.

Badan Standarisasi Nasional. (2016). SNI 17252016 Pembebanan UntukJembatan. Jakarta.

Badan Standarisasi Nasional. (2016). SNI 2833:2016 PerencanaanJembatan Terhadap Beban Gempa.Jakarta. 